\title{
HUBUNGAN STATUS GIZI DAN RIWAYAT MENARCHE IBU DENGAN UMUR MENARCHE PADA SISWI SMP DI BANDAR LAMPUNG
}

\author{
Roza Mulyani* \\ *Jurusan Gizi Poltekkes Tanjungkarang
}

\begin{abstract}
Penelitian berbagai negara menujukan bahwa perbaikan status gizi telah mempercepat usia awal pubertas. Gadis-gadis remaja yang kurang gizi, yang melakukan diit dan berusaha menurunkan berat badan dengan berbagai cara, mengalami kelambatan dalam saat menarchenya. Tujuan penelitian adalah mengetahui hubungan status gizi dan riwayat menarche ibu dengan umur menarche pada siswi SMP di Bandar Lampung. Penelitian ini merupakan penelitian analitik, dengan pendekatan cross sectional, dengan jumlah sampel sebanyak 106 orang siswi yang sudah mendapat mentruasi. Pengumpulan data untuk penilaian status gizi dengan menggunakan IMT/U standar WHO, dengan cara menimbang BB dan mengukur tinggi badan siswi. Hasil penelitian adalah rata-rata umur menarche adalah 11,98 tahun, ratarata umur menarche ibu adalah 13,33 tahun, responden yang berstatus gizi normal sebanyak 61 orang $(57,5 \%)$. Hasil analisis statistik menunjukan tidak ada hubungan antara umur menarche ibu dengan umur menarche, tetapi terdapat hubungan antara status gizi dengan umur menarche. Disarankan meningkatkan kerja sama lintas sektor antara Dinas Kesehatan Kota dan pihak sekolah dengan memberdayakan petugas kesehatan untuk terjun langsung ke sekolah-sekolah dalam program pemantauan status gizi untuk anak usia sekolah
\end{abstract}

Kata kunci: Status gizi, Umur menarche

\section{LATAR BELAKANG}

Masa remaja merupakan suatu tahap antara masa kanak-kanak dengan masa dewasa. Masa ini biasanya diawali pada usia 14 tahun pada laki-laki dan 10 tahun pada perempuan. (Waryana, 2010). Masa remaja adalah suatu periode transisi dari masa anak-anak menjadi kehidupan dewasa, dimana pada periode tersebut terjadi perkembangan pubertas dan maturnitas seksual. Selama pubertas terjadi perubahan hormonal, psikologis, kognitif dan fisik secara simultan dan interaktf yang membuat perkembangan psikologis dalam dimensi emosional, social dan perilaku menjadi suatu tantangan yang harus dihadapi remaja. Masa remaja yaitu masa yang berada pada usia 10 -19 tahun yang merupakan masa yang khusus dan sangat penting, karena merupakan periode pematangan organ reproduksi manusia dan sering disebut sebagai masa pubertas. (Soejitiningsih, 2010).

Data demografi menunjukkan bahwa remaja merupakan populasi yang besar dari penduduk dunia. Sekitar seperlima dari penduduk dunia adalah remaja berumur 10-19 tahun dan sekitar 900 juta berada di negara sedang berkembang. Di Asia Pasifik dimana penduduknya merupakan $60 \%$ dari penduduk dunia, seperlimanya adalah remaja umur 10-19 tahun (Pardede, 2002)

Fase tibanya haid ini merupakan suatu peristiwa dimana remaja telah siap secara biologis menjalani fungsi kewanitaannya (Soejitiningsih, 2010). Pada remaja putri banyak hal-hal yang dapat mempengaruhi menarche, antara lain adanya perubahan hormon yang mempengaruhi kematangan sel dan asupan gizi yang dikonsumsi saat menjelang menarche (Waryana, 2010). Penelitian berbagai negara menujukan bahwa perbaikan status gizi telah mempercepat usia awal pubertas. Gadis-gadis remaja yang kurang gizi, yang melakukan diit dan berusaha menurunkan berat badan dengan berbagai cara, mengalami kelambatan dalam saat menarchenya. Gadis-gadis yang mengalami kekurangan makanan dan bencana kelaparan, sebaliknya akan mengalami penundaan saat menarche (Sukarni, 2012). 
Usia untuk mencapai fase terjadinya menarche dipengaruhi oleh banyak faktor antara lain faktor suku, genetik, gizi, sosial, ekonomi, keterpaparan media massa orang dewasa, perilaku seksual, gaya hidup dan lain-lain. Di Inggris usia rata-rata menarche adalah 13,1 tahun sedangkan di Papua Nugini 18,8 tahun. Secara global dan termutakhir, perempuan mengalami menstruasi karena ketidakseimbangan hormon bawaan lahir. Hal ini juga berkorelasi dengan faktor eksternal asupan gizi pada makanan yang dikonsumsi. Tingkat kualitas gizi yang lebih baik pada masyarakat saat ini, memicu menstruasi dini, tapi gizi kurang juga mengakibatkan hal yang sama. Seperti yang terjadi di Amerika beberapa tahun lalu ditemukan pada sekelompok remaja yang mengalami pendarahan, ternyata mereka bukan mengalami menstruasi, tapi lantaran terlalu banyak mengkonsumsi ayam yang dibesarkan dengan hormon pertumbuhan (Sukarni, 2012).

Di negara maju, perbaikan status gizi mendewasakan fisik anak lelaki dan wanita lebih dini. Pada kelompok remaja ini ratarata usia menarche kini telah anjlok sampai titik 12,8 tahun (Arisman, 2010). Berdasarkan hasil riset kesehatan dasar tahun 2010 terdapat 5.2\% anak- anak di 17 provinsi Indonesia telah memasuki usia menarche di bawah usia 12 tahun. Secara nasional rata-rata usia menarche 13-14 tahun terjadi pada $37,5 \%$ anak Indonesia. Rata-rata usia menarche 11-12 tahun terjadi pada $30,3 \%$ pada anak-anak di DKI Jakarta dan pada provinsi Lampung ratarata usia menarche 13-14 tahun sebesar $40,5 \%$.

Status gizi adalah keadaan yang mencerminkan keseimbangan antara zatzat gizi yang diserap oleh tubuh secara normal yang akan dijadikan energi guna metabolism tubuh secara menyeluruh. Status gizi remaja wanita akan sangat mempengaruhi terjadinya menarche baik dari factor terjadinya menarche, adanya keluhan-keluhan selama menarche maupun lamanya hari menarche. Wanita remaja secara psikologi yang pertama kali akan mengeluh rasa nyeri, perutnya terasa pegal dan kurang nyaman. Tetapi ada juga remaja yang tidak merasakan hal itu, dan itu semua karena asupan gizi yang adekuat. Gizi kurang atau terbatas akan mempengaruhi pertumbuhan fungsi organ tubuh, yang akan menyebabkan terganggunya fungsi reproduksi, hal ini akan mengakibatkangangguan pada haid, tetapi akan berangsur baik bila asupan makanan bernutrisi baik (Proverawati, 2009)

Dari beberapa penelitian yang dilakukan terdapat hubungan antara status gizi dengan usia menarche, antara lain penelitian yang dilakukan oleh Sumini (2014) pada Siswa Sekolah Dasar Kelas 4,5 dan 6 di Sekolah Dasar Negeri Grobokan Kecamatan Karangrejo Kabupaten Magetan, penelitian oleh Sukriani (2010) penelitian pada Sisiwi Kelas VII SMP Muhammadiyah I Jogyakarta dan penelitian yang dilakukan oleh Asyraf (2014) pada Siswi Sekolah Menengah Pertama Negeri 2 Kota Banda Aceh, dimana hasil yang di peroleh ada hubungan antara status gizi dan usia menarche.

Timbulnya menarche juga kebanyakan di tentukan oleh pola dalam keluarga. Faktor genetik berperan mempengaruhi percepatan dan perlambatan menarche yaitu antara usia menarche ibu dengan usia menarce putrinya Hubungan antara usia menarche sesama saudara kandung lebi erat daripada antara ibu dan anak perempuannya (Perdede, 2002). Dalam penelitian yang dilakukan oleh Ersoy, B.et.al (2005) dalam Wulansari (2012) menyatakan bahwa terdapat hubungan antara usia menarche ibu dan anak perempuannya, hanya terpaut sekitar 1 tahun, dimana usia anak saat menarche adalah 12.82 tahun dan usia ibu saat menarche adalah 13,6 tahun. Penelitian yang dilakukan oleh Simatupang (2014), pada remaja SMP di Kecamatan Banyumanik Kota Semarang dan Kisswardhani (2014) pada siswi SMP Negeri I Subah Kabupaten Batang terdapat hubunga antara genetik dengan usia menarche. 


\section{METODE}

Penelitian ini merupakan penelitian survey yang bersifat analisis kuantitatif, dengan pendekatan cross sectional. Penelitan dilakukan di SMPN 29 Bandar Lampung, dangan lama penelitian kurang lebih 1 bulan. Populasi dalam penelitian ini adalah seluruh siswi kelas VII dan VIII pada salah satu SMP di Bandar Lampung berjumlah 286 orang, dengan jumlah sampel adalah sebanyak 106 orang terdiri dari siswi kelas VII 54 orang dan kelas VIII 52 orang.

Data yang dikumpulkan menggunakan timbangan detecto dan microtoise serta tabel IMT/U untuk status gizi dan riwayat manerche menanyakan dengan alat bantu kuesioner. Data yang diperoleh dianalisa secara univariat dan bivariat menggunakan uji Anova dan Korelasi pearson product moment.

\section{HASIL}

\section{Analisa Univariat}

Rata-rata umur menarche responden adalah 11,98 tahun. Responden termuda menarche berumur 9 tahun sedangkan umur tertua menarche adalah 14 tahun.Terdapat $51 \quad(48,1 \%)$ responden umur menarchenya di usia 12 tahun.

Status gizi responden dalam penelitian ini, sebanyak 25 orang $(23,6 \%)$ status gizi kurus atau kurang, 61 orang $(57,5 \%)$ berstatus gizi normal, dan sebanyak 20 orang $(18,9 \%)$ berstatus gizi gemuk (lebih).

Rata-rata umur ibu menarche adalah 13,33 tahun. Usia ibu termuda menarche berumur 11 tahun sedangkan usia tertua menarche adalah 16 tahun.

Umur menarche ibu pada usia 13 tahun sebanyak $33(31,1 \%)$ orang, sedangkan usia menarche ibu pada usia 11 tahun dan usia 16 tahun terdapat sama banyaknya yaitu $5(4,7 \%)$ orang.

\section{Analisa Bivariat}

Tabel 1: Hubungan Status Gizi Dengan Umur Menarche

\begin{tabular}{lccccc}
\hline & & \multicolumn{4}{c}{ Umur Menarche } \\
\cline { 3 - 5 } Status Gizi & f & Mean & SD & $\begin{array}{c}95 \% \\
\text { CI }\end{array}$ & $\begin{array}{c}p \\
\text { value }\end{array}$ \\
\hline Kurus & 25 & 12,48 & 0,71414 & $\begin{array}{c}12,1852- \\
12,7748\end{array}$ & \\
\hline Normal & 61 & 11,86 & 0,88460 & $\begin{array}{c}11,6423- \\
12,0954\end{array}$ & 0,006 \\
\hline Gemuk & 20 & 11,70 & 1,12858 & $\begin{array}{c}11,1718- \\
12,2282\end{array}$ \\
\hline
\end{tabular}

Pada tabel di atas terlihat bahwa ratarata umur menarche responden status gizi kurus adalah 12,48 \& dengan standar deviasi 0,71414. Pada kelompok responden status gizi normal rata-rata umur menarche adalah 11,86 dengan standar deviasi 0,88460, dan rata-rata umur menarche responden status gizi gemuk adalah 11,70. Hasil uji statistik didapat nilai $\mathrm{p}=0,006$, berarti ada hubungan status gizi dengan umur menarche.

Tabel 2: Hubungan Umur Menarche Ibu dengan Umur Menarche

\begin{tabular}{ccc}
\hline \multirow{2}{*}{ Variabel } & \multicolumn{2}{c}{ Umur Menarche } \\
\cline { 2 - 3 } & $\mathrm{r}$ & $p$ value \\
\hline Umur menarche ibu & 0,190 & 0,052 \\
\hline
\end{tabular}

Pada tabel di atas terlihat hubungan umur menarche ibu dengan umur menarche responden menunjukan hubungan yang lemah ( $\mathrm{r}=0,190)$ yang artinya tidak ada hubungan antara umur menarche ibu dengan umur menarche. Hasil uji statistik didapatkan tidak ada hubungan yang signifikan antara umur menarche ibu dan umur menarche $(\mathrm{p}=0,052)$.

\section{PEMBAHASAN}

\section{Umur Menarche}

Menarche adalah periode menstruasi yang pertama terjadi pada masa pubertas seorang wanita atau dapat juga diartikan sebagai permulaan menstruasi pada 
seorang gadis pada masa pubertas, yang biasanya muncul pada usia 11 sampai 14 tahun. Perubahan penting yang terjadi pada masa si gadis menjadi matang jiwa dan ragannya melalui masa remaja wanita dewasa. Hal ini menandakan bahwa anak tersebut sudah memasuki tahap kematangan organ seksual dalam tubuhnya (Sukarni, 2012)

Dalam penelitian ini yang dilakukan terhadap siswi SMPN 29 Bandar Lampung tahun 2016 sebanyak 106 responden diperoleh hasil rata-rata umur menarche adalah 11,98 tahun, dengan median 12,00 tahun. Dimana responden dengan usia termuda menarche berumur 9 tahun sedangkan usia tertua menarche berumur 14 tahun. Hasil penelitian ini tidak jauh berbeda dengan hasil riset kesehatan departemen Kesehatan Republik Indonesia melaporkan terjadi penurunan usia menarche di Indonesia. Berdasarkan hasil riset kesehatan dasar tahun 2010 terdapat $5.2 \%$ anak- anak di 17 provinsi Indonesia telah memasuki usia menarche di bawah usia 12 tahun. Rata- rata usia menarche yang di peroleh dalam penelitian ini lebih muda yaitu rata-rata dibawah 12 tahun, dibandingkan dengan usia menarche secara nasional rata-rata usia menarche 13-14 tahun terjadi pada $37,5 \%$ anak Indonesia. dan di Provinsi Lampung rata-rata usia menarche 13-14 tahun sebesar 40,5\%.

Rata - rata umur menarche pada penelitian sejalan dengan penelitian yang dilakukan oleh Aryati (2008), pada siswi SD dan SLTP di kota Bandung dimana rata- rata usia menarche dibawah usia 12 tahun yaitu 11,61 tahun. Hasil penelitian ini usia menarche termasuk katagori usia manerche normal karena kebanyakan usia responden mulai menstruasi pada usia 11 13 tahun, terdapat juga responden yang usia menarche 9 tahun sebanyak 2 orang sedangkan mulai menarche pada usia 14 tahun ada 4 responden.

Usia menarche yang terjadi terlalu lambat maupun terlalu cepat berdampak buruk bagi kesehatan, yang cepat dapat meningkatkan penyakit kardiovaskular (Karen, dkk, 2005). dalam Aryati (2008. Menarche yang cepat dimungkinkan dipengaruhi oleh factor genetik, status gizi dan factor lingkungan. Faktor lingkungan disini juga termasuk media massa yang berkaitan dengan media massa bacaan, gambar maupun audio visual yang dapat menimbulkan rangsangan seksual seseorang. Selain itu lingkungan tempat tinggal juga mempengaruhi usia menarche, dilingkungan perkotaan memiliki rata-rata usia menarche yang lebih dini dibandingkan daerah pedesaan.

Pada penelitian ini diperoleh hasil umur menarche lebih muda yaitu dibawah usia 12 tahun, hal ini kemungkinan di pengaruhi oleh beberapa faktor diantaranya keadaan gizi hal ini terlihat dari penilaian status gizi responden kebanyakan berstatus gizi baik dan terdapat juga berstatus gizi gemuk (lebih), lingkungan dari remaja itu sendiri tinggal di Bandar Lampung yang termasuk katagori daerah perkotaan yang banyak dijumpai makanan cepat saji yang dijual, makanan bergizi tapi kaya akan lemak dan protein hewani, dimana dikonsumsi berlebihan akan meningkatkan kadar estrogen yang mempengaruhi pertumbuhan hormon reproduksi sehingga menarche timbul lebih cepat dari batas normal, pengaruh lingkungan lainya termasuk media massa, seperti bacaan, gambar, audio social yang dapat merangsang seksual seseorang yang lebih banyak dijumpai di perkotaan dan status sosial ekonomi dari orang tua. Status sosial ekonomi seorang remaja dari kalangan ekonomi rendah akan berdampak pada makanan yang dikonsumsinya misalnya mereka makan seadanya tanpa memikirkan kandungan gizinya, sebaliknya remaja dari kalangan ekonomi tinggi, mereka lebih mudah mendapatkan makanan yang disukainya karena didukung oleh pendapatan yang diperoleh.

Menurut Waryana (2010) usia menarche yang semakin menurun ini dapat menyebabkan masalah yang bersumber pada organ biologik akibat pematangan organ-organ reproduksi yang akan memberikan dorongan psikologik dan emosional tertentu, salah satunya kehamilan yang tidak di kehendaki / kehamilan dini. Selain itu menarche yang 
terlampau dini dikaitkan faktor resiko beberapa penyakit keganasan seperti kanker ovarium. Sedangkan menarche yang lambat dapat menyebabkan menopause seseorang menjadi cepat. Belakangan insiden kanker uterus dan kanker payudara dikaitkan dengan usia menarche oleh alasan hormonal yang dalam hal ini didominasi oleh hormon estrogen.

Menarche dini memang dapat mengakibatkan resiko penyakit seperti yang telah disebutkan diatas namun menarche dini ini tidak dapat dicegah karena semakin hari tingkat ekonomi masyarakat di perkotaan seperti Bandar Lampung terus meningkat yang berkorelasi dengan kemampuan masyarakat untuk membeli makanan yang bergizi untuk pertumbuhan dan perkembangan anaknya sehingga akan mempengaruhi status gizi dari seorang anak. Untuk faktor resiko penyakit yang diakibatkan oleh menarche dini dapat kita cegah dengan cara menjaga pola makan yang seimbang dan menjaga kebersihan organ kewanitaan.

Orang tua hendaknya mempersiapkan anaknya yang mulai tumbuh menjadi remaja untuk mengahadapi menarche seperti memberikan pengetahuan seks agar nanti anaknya tidak kebingungan dengan hal-hal baru yang terjadi kepada nya serta kesiapan psikologis anak untuk mengahadapi menarche. Begitu pula dengan pihak sekolah hendaknya selalu memberikan pendidikan kesehatan, gizi dan reproduksi dengan memberdayakan Usaha Kesehatan Sekolah (UKS) sebagai wadah para siswi mengetahui pentingnya kesehatan, gizi dan reproduksi.

\section{Status Gizi}

Status gizi adalah ekspresi dari keadaan keseimbangan dalam bentuk variabel tertentu atau perwujudan dari nutriture dalam bentuk variabel (Supariasa, 2002). Pengukuran status gizi untuk remaja dapat menggunakan perhitungan IMT namun yang membedakan adalah pengklasifikasian hasil dari perhitungan IMT tersebut, berdasarkan Keputusan Menteri Kesehatan RI Nomor 1995/MENKES/SK/XII/2010 tentang standar antropometri penilaian status gizi anak, status gizi untuk usia 5-18 tahun berdasarkan umur dibedakan menjadi 5 yaitu sangat kurus (<-3 SD), Kurus (- 3SD s.d <-2 SD), Normal (-2SD s.d 1 SD), Gemuk (>1 SD s.d 2 SD), Obesitas (> 2SD).

Berdasarkan hasil penelitian diketahui bahwa dari 106 responden didapatkan sebanyak 25 orang $(23,6 \%)$ status gizi kurus (kurang), 61 orang $(57,5 \%)$ berstatus gizi normal, dan sebanyak 20 orang $(18,9 \%)$ berstatus gizi gemuk (lebih)..

Gizi mempengaruhi kematangan seksual pada remaja yang mendapat menarche lebih dini. Pada umumnya, mereka yang menjadi matang lebih dini akan memiliki Indeks Masa Tubuh (IMT) yang lebih tinggi dan mereka yang matang terlambat memiliki IMT lebih kecil pada usia yang sama (Waryana,2010).

Menurut Wiknjosastro (2011) salah satu yang mempengaruhi usia menarche yaitu status gizi. Makin baiknya status gizi mempercepat usia menarche. Beberapa ahli mengatakan anak perempuan dengan jaringan lemak yang lebih banyak, lebih cepat mengalami menarche dari pada anak yang kurus.

Hasil analisis bivariat terlihat bahwa rata-rata umur menarche responden status gizi kurus (kurang) adalah 12,48 tahun, pada kelompok responden status gizi normal rata-rata usia menarche adalah 11,86 tahun, sedangkan rata-rata umur menarche responden status gizi gemuk adalah 11,70 tahun, dari hasil ini dapat dilihat status gizi berperan dalam menentukan usia menarche, hasil uji statistik didapat nilai $\mathrm{p}=0,006$, berarti ada hubungan signifikan antara status gizi dengan usia menarche. Penelitian ini sejalan dengan penelitian Aryati (2007) di SD dan SLYP Kota Bandung diperoleh hasil ada hubungan antara status gizi dengan usia menarche, juga sejalan dengan penelitian Sumini (2014), Sukriani (2010) dan Asyraf (2014). Pehelitian Amaliah, dkk (2012) Terdapat perbedaan yang 
signifikan rata-rata usia menarche remaja yang berstatus tinggi badan normal dengan yang pendek. Rata-rata usia menarche remaja dengan tinggi badan normal lebih cepat dari remaja pendek

Berdasarkan hasil penelitian status gizi remaja siswi SMPN 29 Bandar Lampung ini adalah normal dan ada yang berlebih (gemuk), hal ini kemungkinan dikarenakan dari pola konsumsi dan asupan makanan responden yang mana kemudahan bagi mereka untuk memperoleh makanan baik di lingkungan rumah maupun di sekolah yang biasanya banyak menjual makanan cepat saji yang kaya akan kalori, lemak dan protein, serta aktivitas fisik responden, dimana lingkunan sekolah yang cukup luas dan adanya lapangan olahraga memungkinkan mereka lebih aktif untuk bergerak/olahraga. Dengan status gizi yang baik dapat membuat seorang remaja dapat tumbuh dengan yang seharusnya. Karena untuk pertumbuhan yang normal diperlukan nutrisi yang adekuat di dalam tubuh, serta diikuti dengan aktifitas fisik yang cukup.

Berdasarakan hasil penelitian terdapat $23,6 \%$ yang status gizinya kurus (kurang) tetapi rata-rata usia menarchenya masih termasuk katagori normal $(12,48$ tahun), hal ini kemungkinan peran social ekonomi orang tua, genetik yaitu usia ibu pertama kali menstruasi dan factor lingkungan seperti pengaruh media massa, bacaan, gambar-gambar atau audio visual yang meningkatkan rangsangan seksualitas seseorang.

Kekurangan nutrisi pada seseorang akan berdampak pada penurunan fungsi reproduksi. Pada wanita anoreksia kadar hormon steroid mengalami perubahan yaitu meningkatkan kadar testosterone serum dan penurunan sekresi 17-keto steroid dalam urine, diantaranya androsteron dan epioandrosteron, dampaknya terjadi perubahan siklus ovulasi. Seseorang yang mendapatkan asupan gizi yang baik atau gizi yang lebih maka akan mempengaruhi hormon pertumbuhan tubuh khususnya akan mempercepat kematangan hormon reproduksi untuk mendapatkan menarche dini atau tepat pada waktunya, begitu juga sebaliknya seseorang yang mendapatkan asupan gizi yang kurang akan menyebabkan penurunan fungsi reproduksi yang mengakibatkan lamanya menarche. (Waryana, 2010). Masih dijumpainya masalah gizi dalam penelitian ini yaitu status gizi kurus dan status gizi gemuk pada siswi SMPN 29 Bandar Lampung, diharapkan pihak sekolah meningkatkan kerjasama lintas sektor dengan Dinas Kesehatan Kota dengan memberdayakan petugas kesehatan untuk terjun langsung ke sekolah-sekolah dalam program pemantauan status gizi untuk anak usia sekolah

\section{Riwayat Menarche Ibu}

Selain dari factor status gizi, timbulnya menarche juga kebanyakan di tentukan oleh pola dalam keluarga. Faktor genetik berperan mempengaruhi percepatan dan perlambatan menarche yaitu antara usia menarche ibu dengan usia menarce putrinya Hubungan antara usia menarche sesama saudara kandung lebih erat daripada antara ibu dan anak perempuannya (Perdede, 2002).

Dalam penelitian ini diperoleh hasil rata-rata umur ibu menarche adalah 13,33 tahun, dengan median 13,00 tahun. Usia ibu termuda menarche berumur 11 tahun sedangkan usia tertua menarche adalah 16 tahun. Hasil penelitian Aryati (2008) ratarata usia menarche ibu adalah 12,96 tahun lebih muda dibandingkan hasil penelitian ini. Dari hasil analisa bivariat tidak ada hubungan yang signifikan antara umur ibu dan umur menarche dengan $\mathrm{p}=0,052$. Penelitian ini sejalan dengan penelitian Aryati (2008), dan penelitian ini tidak sejalan dengan penelitian yang dilakukan oleh Simatupang (2014), pada remaja SMP di Kecamatan Banyumanik Kota Semarang dan Kisswardhani (2014) pada siswi SMP Negeri I Subah Kabupaten Batang terdapat hubungan antara genetik dengan usia menarche.

Tidak ada pengaruh faktor genetik yaitu usia ibu pertama kali menarche dengan usia menarche responden dalam 
penelitian ini kemungkinan dikarenakan dalam menyebutkan umur menarche ibu tidak ingat betul kapan mereka pertama kali menstruasi karena waktunya sudah lama, sehingga mereka mungkin banyak hanya mengira-ngira usia menarchenya. Di karenakan keterbatasan peneliti tidak menanyakan langsung data usia menarche ibu responden, tetapi menyuruh responden untuk menanyakan ke ibu mereka di umur berapa ibunya menarche, kemungkinan terjadi bias informasi, dimana responden mungkin juga kurang tepat memberikan informasi, kemungkinan hal ini jiga menyebabkan tidak ada hubungan antara umur menarche ibu dengan umur menarche dalam penelitian ini.

\section{KESIMPULAN}

Rata-rata umur menarche pada siswi di salah satu SMP di Bandar Lampung adalah 11,98 tahun, 61 orang $(57,5 \%)$ berstatus gizi normal, rata-rata umur menarche ibu adalah 13,33 tahun. Analisis lebih lanjut meyimpulkan ada hubungan status gizi dengan umur menarche dan tidak ada hubungan antara umur menarche ibu dengan umur menarche responden.

Dari kesimpulan tersebut disarankan untuk meningkatkan kerja sama antara Dinas Kesehatan Kota dan sekolah dengan memberdayakan petugas kesehatan untuk terjun langsung ke sekolah untuk pemantauan status gizi. Pihak sekolah hendaknya selalu memberikan pendidikan kesehatan kepada para siswi mengetahui pentingnya kesehatan gizi dan reproduksi

\section{DAFTAR PUSTAKA}

Amaliah, N. dkk, (2012). Status Tinggi Badan Pendek Beresiko Terhadap Keterlambatan Usia Menarche Pada Perempuan Remaja Usia $10 \quad-15$ Tahun. Jurnal Penelitian Gizi Makanan, Volume 35 No 2.

Arisman. 2010. Ilmu Gizi dalam Daur Kehidupan. Jakarta: EGC.
Aryati, Dian, 2008. Usia Menarche Pada Siswi SD dan SLTP di Kota Bandung. Jurnal Kesehatan Masyarakat Nasional, Volume 2 No 6 Juni 2008

Kisswardhani, A.D. (2014). Hubungan antara Status Gizi, Tingkat Paparan Media Massa dan Faktor Keturunan dengan Usia Menarche pada Siswi di SMP Negeri I Subah Kabupaten Batang, Skripsi. Universitas Muhammadiyah Surakarta.

Pardede dkk. 2002. Tumbuh Kembang Anak dan Remaja. Jakarta. EGC

Proverawati, A. 2009. Gizi Untuk Kebidanan. Yogyakarta:Nuha Medika.

Soetjiningsih. 2010. Tumbuh Kembang Remaja dan Permasalahannya. Jakarta:CV Sagung Seto.

Sumini, 2014. Hubungan Status Gizi dengan Usia Menarche pada Siswi Sekolah Dasar Kelas 4,5 dan 6 di Sekolah Dasar Negeri Grobokan Kecamatan Karangrejo Kabupaten Magelang, Jurnal Delima Harapan, 1-9.

Simatupang, R. (2014). Faktor-faktor yang Berhubungan dengan Usia Menarche pada remaja SMP di Kecamatan Banyumanik Kota Semarang. Skripsi. Universitas Diponegoro.

Sukriani, W. (2010). Hubungan Status Gizi dengan Usia Menarche Siswi Kelas VII SMP Muhammadyah I Jogyakarta, Skripsi. STIKES Aisiyah Jogyakarta.

Sukarni K, Icemi. 2012. Keperawatan Maternitas. Jakarta: Fitramaya

Waryana. 2010. Gizi Reproduksi. Jogjakarta (ID) : Pustaka Rihama.

Wiknjosastro, H, 2011. Ilmu Kandungan. Jakarta. Yayasan Bina Pustaka

Wulansari, N.A. (2012). Hubungan Konsumsi Junk Food dan Media Informasi terhadap Menarche Dini pada Siswi Sekolah Dasar di Surakarta. Skripsi. Universitas Muhammadiyah Surakarta. 